Religion in the Public Square 
This page intentionally left blank 


\section{RELIGION IN THE PUBLIC SQUARE}

Sheen, King, Falwell

James M. Patterson

\section{PENN}

UNIVERSITY OF PENNSYLVANIA PRESS

PHILA DELPHIA 
Copyright @ 2019 University of Pennsylvania Press

\author{
All rights reserved. \\ Except for brief quotations used for purposes of review or scholarly citation, \\ none of this book may be reproduced in any form by any means \\ without written permission from the publisher. \\ Published by \\ University of Pennsylvania Press \\ Philadelphia, Pennsylvania 19104-4112 \\ www.upenn.edu/pennpress
}

Printed in the United States of America

on acid-free paper

13579108642

Library of Congress Cataloging-in-Publication Data

Names: Patterson, James M. (James McGill), author.

Title: Religion in the public square: Sheen, King, Falwell / James M. Patterson.

Description: 1st edition. | Philadelphia: University of Pennsylvania Press, [2019] | Includes bibliographical references and index.

Identifiers: LCCN 2018045748 | ISBN 9780812250985 (hardcover)

Subjects: LCSH: Christianity and politics-United States-History-20th century. |

Church and state-United States-History-20th century. | Sheen, Fulton J. (Fulton John),

1895-1979. | King, Martin Luther, Jr., 1929-1968. | Falwell, Jerry. | United States-Politics

and government-20th century. | United States-Religion-History-20th century.

Classification: LCC BR526.P375 2019 | DDC 261.70973/0904-dc23

LC record available at https://lccn.loc.gov/2018045748 
Dedicated to

Maria Sedes Sapientiae 
This page intentionally left blank 